\title{
Utilization of Recombinant Human Bone Morphogenetic Protein on the Reconstruction of Critical Defect on Maxilla
} Erika Storck Cezário ${ }^{1,2 *}$, Clayton Cássio Thomaz Fróis ${ }^{3}$, Regiane Brito de Assis ${ }^{1}$, Emiliano Mansur Abreu, ${ }^{1,2}$, Flávia Rodrigues Caetano Batista de Paiva ${ }^{2}$, Maurício Greco Côsso ${ }^{2}$

\author{
${ }^{1}$ Unileste Dental Medicine School, Ipatinga, Minas Gerais, Brazil. \\ ${ }^{2}$ Pontifical CatholicUniversityof Minas Gerais Dental Medicine School, Belo Horizonte, Minas Gerais, Brazil. \\ ${ }^{3}$ Private Clinic, Coronel Fabriciano, Minas Gerais, Brazil. \\ storckcezario@gmail.com \\ *Corresponding Author: Dr. Erika Storck Cezário, Unileste Dental Medicine School, Ipatinga, Minas Gerais, Brazil.
}

\section{Abstract}

Objective: The aim of this study was to report a case of utilization of recombinant human bone morphogenetic protein-2 on bony regeneration of anterior maxilla.

Case Report: 39 years old female patient, non-smoker and without systemic complication was referred to dental evaluation because of dental esthetic dissatisfaction. After clinical and tomographic examination a defect class III of Seibert was observed six months after extraction of teeth 12 and 11. Because of defect's morphology augmentation by autogenous bone block was not allowed. Alveolar ridge augmentation was realized utilizing rhBMP-2. After 12 months a new tomography revealed bone augmentation that allowed implant installation.

Discussion: rhBMP-2 has been utilized for induction of bone formation for different critical defects including alveolar ridge defects.

Conclusion: The clinical results observed on this study allowed reconstruction of alveolar ridge and adequate tridimensional implant installation on anterior maxilla.

Keywords: maxilla; alveolar ridge augmentation; guided bone regeneration; recombinant human bone morphogenetic protein- $2 \mathrm{~h}$

\section{INTRODUCTION}

Critical ridge defects in the anterior maxilla region are one of the most challenging cases in Implantology. In spite of advances in biomaterials and the development of new techniques for bone reconstruction, the increase of bone volume for the appropriate three dimensional implant installation in these areas is of great complexity ${ }^{1,2}$.

As a gold standard the autogenous bone graft is considered the ideal material when compared to others since it presents osseoinducing, osseo conductive and osteogenic properties. However, obtaining autogenous bone involves the approach of another surgical site besides representing greater morbidity for the patient ${ }^{3}$.

The human recombinant morphogenetic protein 2 (rhBMP2) associated with absorbable collagen sponge (ACE) has been used since 2007 in procedures for maxillary sinus lift and alveolar preservation ${ }^{4}$. However, there is still a shortage in the literature on the reconstruction of critical defects in the anterior region of the maxilla using this biomaterial.

In this sense, the objective of the present study was to report a case of alveolar ridge reconstruction in the aesthetic area prior to implant installation with rhBMP2.

\section{CASE REPORT}

Patient 39 years old, female, non-smoker and without systemic involvement was referred to the Specialization in Implant Dentistry course of the Brazilian Dental Association in the city Ipatinga, Minas Gerais, Brazil, due to her dissatisfaction with dental aesthetics. Teeth 11 and 12 were extracted six months before. A Class III defect of Seibert was observedin the region (Figure 1). 
Utilization of Recombinant Human Bone Morphogenetic Protein on the Reconstruction of Critical Defect on Maxilla

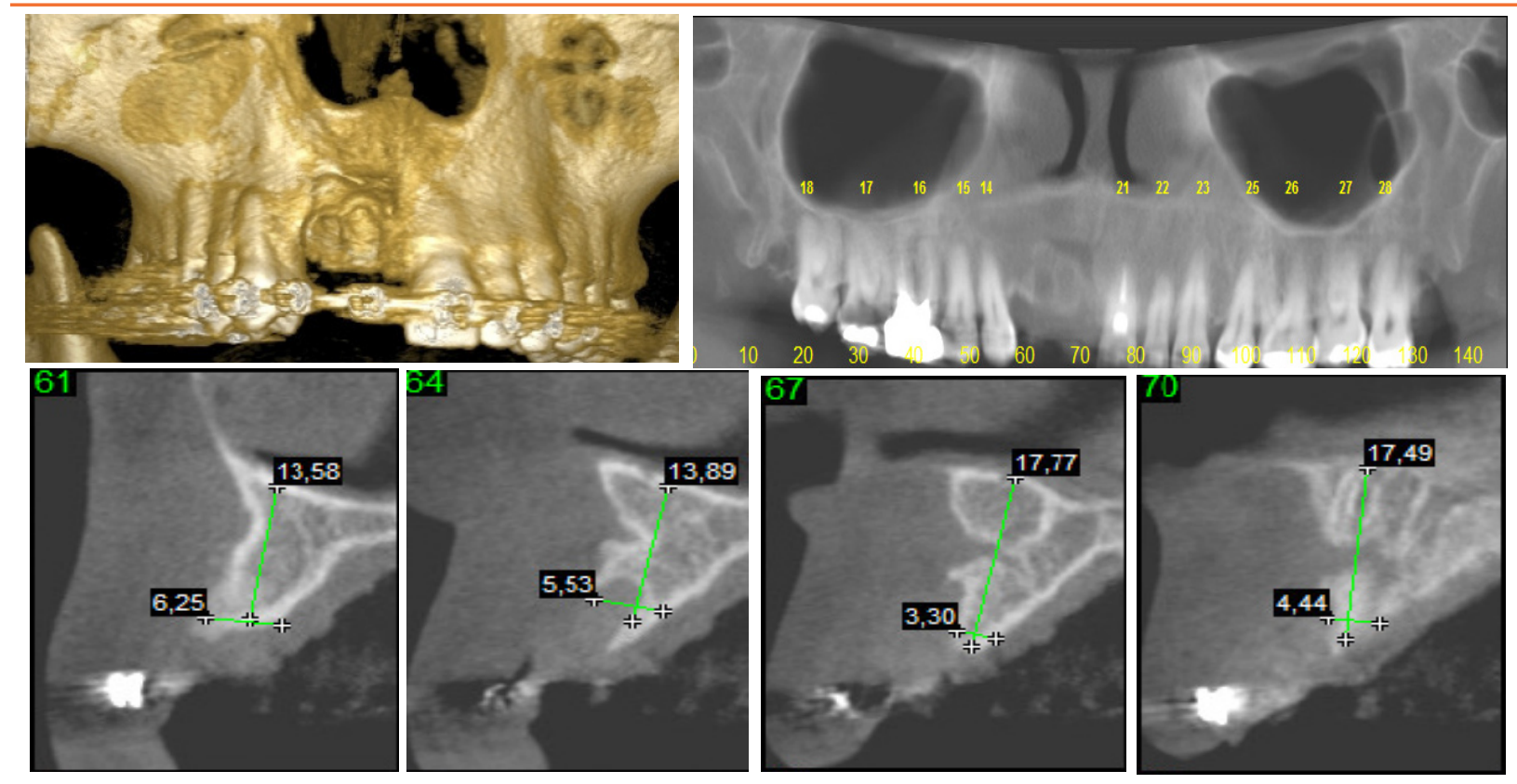

Fig 1. Tomographic images prior ridge augmentation

Due to the morphology of the defect that made autogenous block graft unfeasible, an alveolar ridge augmentation procedure was performed using rhBMP-2 (Infuse, Medtronic, USA) associated with ACE.

The procedure for placing the biomaterial was performed under local anesthesia (Alphacaine 1: 100000; DFL, Brazil). Two vertical incisions and a horizontal crest incision were performed and a total flap was folded. The defect was debrided in order to remove the granulation tissue and the rhBMP-2 preparation was made following the manufacturer's recommendations.
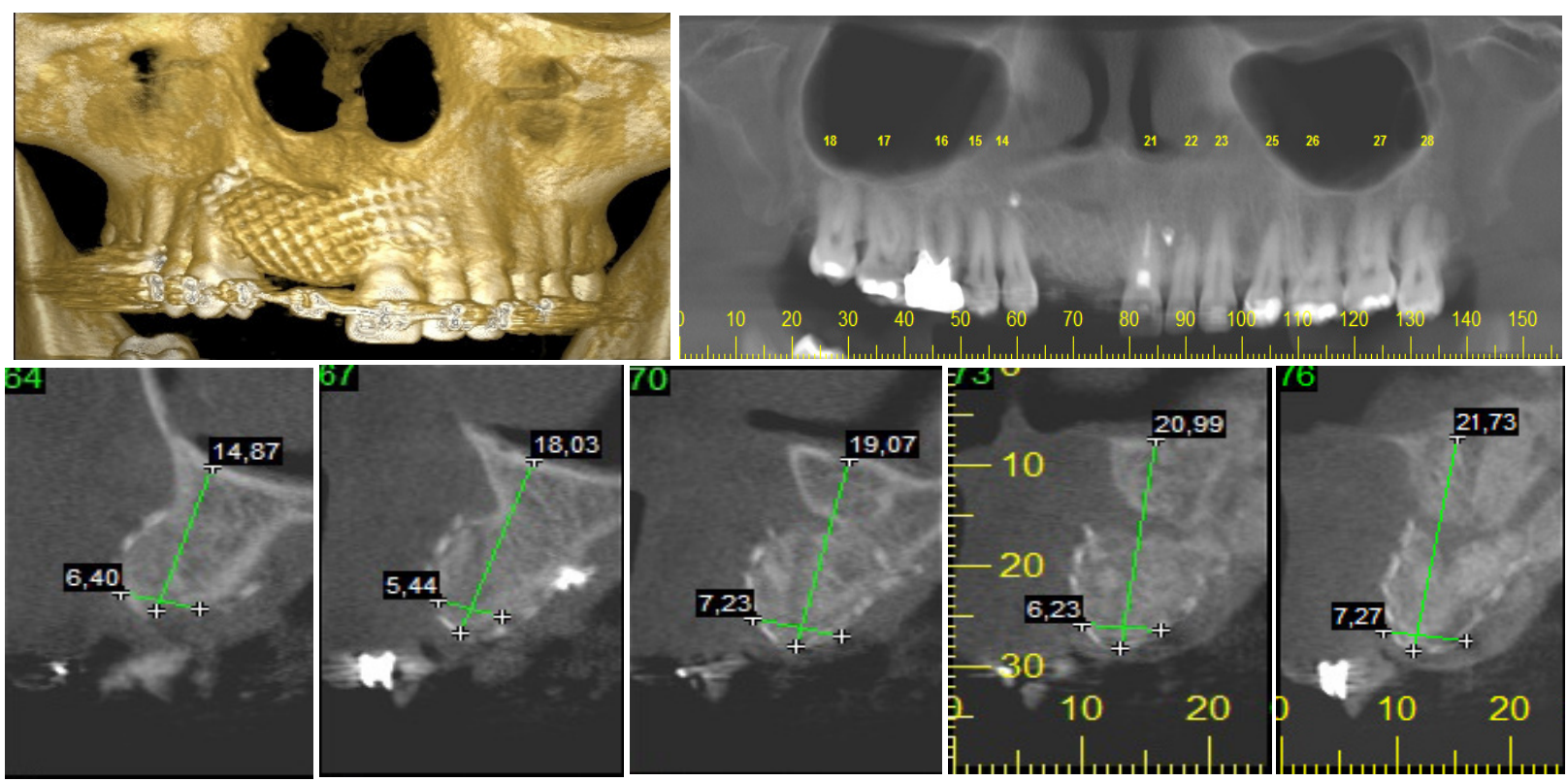

Fig 2. Tomographic images after ridge augmentation 

on Maxilla

A new total flap for titanium screen removal and to teeth 11 and $12,4.1 \times 12 \mathrm{~mm}$ and $3.4 \times 12 \mathrm{~mm}$, placement of the implants in the areas corresponding respectively was made (Figure 3).

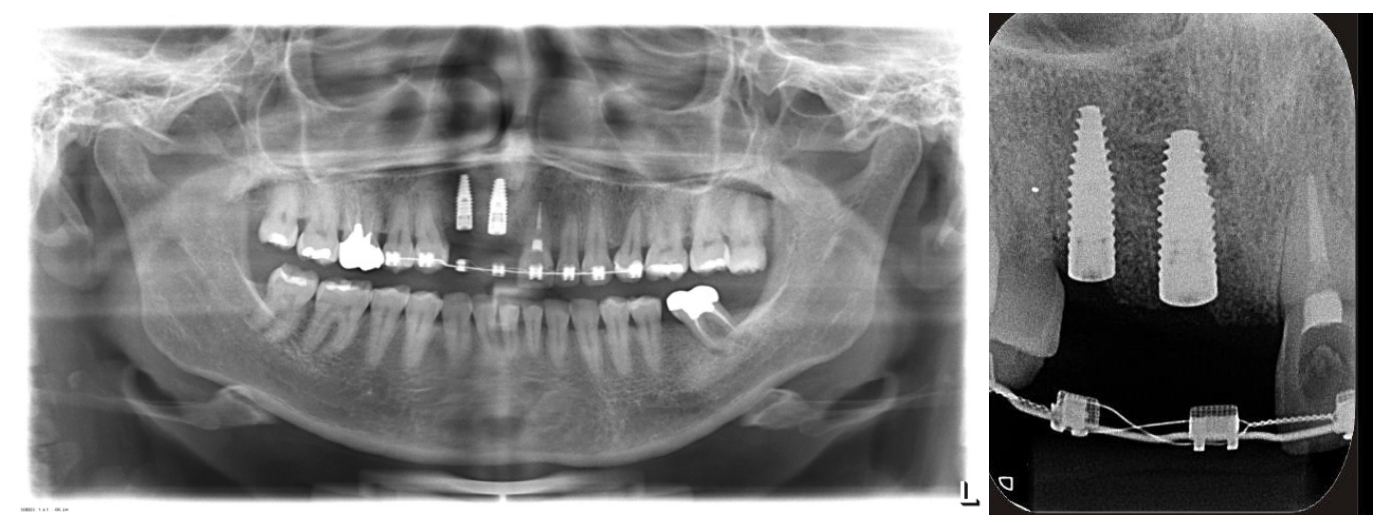

Fig 3. Implants installed in the anterior area
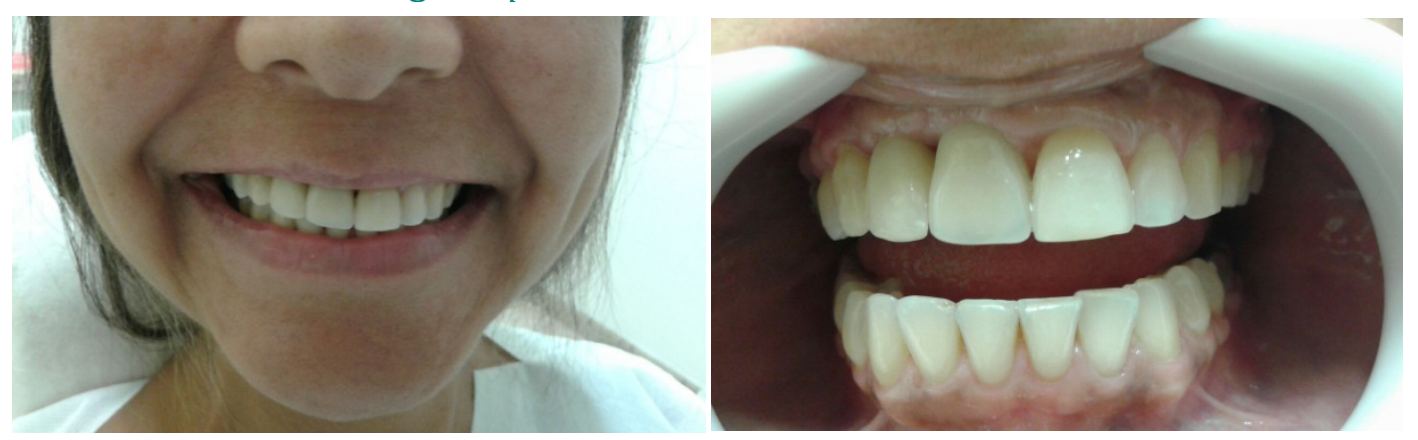

Fig 4. Provisional acrylic crowns

\section{DiscuSSION}

The loss of teeth is frequently associated with alveolar resorption and results in defects in the ridge that may make rehabilitation via implants unfeasible ${ }^{5}$. Especially in the anterior region of the maxilla this situation constitutes a challenge for surgical and prosthetic reconstructions.

As a gold standard, autogenous bone graft is considered the ideal material when compared to other materials since it has osseoinductive, osseo - conductive and osteogenic properties. However, obtaining autogenous bone involves the approach of another surgical site and greater morbidity for the patient. As an alternative, bone substitutes such as rhBMP-2, hydroxyapatite and bioactive glasses have been employed in alveolar ridge augmentation procedures ${ }^{3}$.

Although rhBMP-2 has been released since 2007 for craniofacial reconstructions, few studies have evaluated its use in critical defects in the anterior region of the maxilla ${ }^{5-8}$.

The growth factors stimulate the migration of mesenchymal cells and angiogenesis around the bone tissue promoting a path for osteoprogenitor cells and new bone formation. Thus, the morphology of a bone defect dictates the choice of material and technique to be employed. Sites with few bone walls and severe alveolar resorptions require materials with increased biological activity and regenerative capacity ${ }^{7}$. In the case presented here, the defect was of considerable extension with one bone wall and the anterior maxilla area. In view of the impossibility of autogenous block grafting, we chose to use rhBMP-2, which obtained excellent results.

In a randomized clinical study ${ }^{6}$, the authors observed that rhBMP-2 provided a significantly greater bone gain when compared to autogenous bone graft in the anterior maxilla. In the present case report, the use of rhBMP-2 for the reconstruction of a critical defect in the anterior region of the maxilla made possible the rehabilitation through implants.

The literature reports that the rehabilitation of the aesthetic area of the maxilla is a complex task since it also involves high expectations and demands on the part of patients, especially in women ${ }^{9}$. In the rehabilitation of the present case, the patient had a 
high aesthetic requirement and an excellent aesthetic harmony was achieved. However, it is important to note that, in order to obtain these results, it was necessary to reconstruct the defect in order to allow the appropriate three-dimensional implant installation ${ }^{10}$.

\section{CONCLUSIONS}

The use of rhBMP-2 for bone augmentation in the anterior maxilla region was a viable alternative in the present case for the adequate installation of implants and subsequent prosthetic rehabilitation.

\section{REFERENCES}

[1] Saadat F, Mosharraf R. Prosthetic management of an extensive maxillary alveolar defect with an implant-supported restoration. J Dent. 2013; 10: 256-63.

[2] Urban IA, Monje A, Nevins M, Nevins ML, Lozada JL, Wang HL. Surgical management of significant maxillary anterior vertical ridge defects. Int J Periodontics Restorative Dent. 2016; 36: 32937.

[3] Browaeys H, Bouvry P, De Bruyn H. A literature review on biomaterials in sinus augmentation procedures. Clin Implant Dent Relat Res. 2007; 9: 166-77.

[4] Spagnoli DB, Marx RE. Dental implants and the use of rhBMP-2. Oral MaxillofacSurgClin North Am. 2011; 23: 347-61.

[5] Ribeiro Filho SA, Francischone CE, de Oliveira JC, Ribeiro LZ, do Prado FZ, Sotto-Maior BS. Bone augmentation of the atrophic anterior maxilla for dental implants usng rhBMP-2 and titanium mesh: histological and tomographic analysis. Int J Oral Maxillof Surg. 2015; 44: 1492-98.

[6] de Freitas RM, Susin C, Spin-Neto R, Marcantonio C, Wikesjö UM, Pereira LA et al. Histological ridge augmentation of the atrophic anterior maxilla using rhBMP-2/ACS or autogenous bone grafts: a proof-of-concept randomized clinical trial. J ClinPeriodontol. 2013; 40: 968-75.

[7] Misch CM, Jensen OT, Pikos MA, Malmquist JP. Vertical bone augmentation using recombinant bone morphogenetic protein, mineralized bone allograft, and titanium mesh: a retrospective cone beam computed study. Int J Oral Maxillofac Implants. 2015; 30: 202-7.

[8] de Freitas RM, Susin C, Tamashiro WM, Chaves de Souza JA, Marcantanio C, Wikesjö UM et al. Histological analysis and gene expression profile following augmentation of the anterior maxilla using rhBMP-2/ACS versus bone graft. J ClinPeriodontol. 2016; 43: 1200-07.

[9] Chen ST, Buser D Esthetic outcomes following immediate and early implant placement in the anterior maxilla: a systematic review. Int J Oral Maxillofac Implants. 2014; 29: 186-215.

[10] MirandaDA,BlumenthalNM,SorensenRG,Wozney JM, Wikesjö UM. Evaluation of recombinant human bone morphogenetic protein-2 on the repair of alveolar ridge defects in baboons. J Periodontol. 2005; 76: 210-20.

Citation: Erika Storck Cezário, Clayton Cássio Thomaz Fróis, et al. Utilization of Recombinant Human Bone Morphogenetic Protein on the Reconstruction of Critical Defect on Maxilla. Archives of Dentistry and Oral Health. 2019; 2(1): 01-04.

Copyright: (c) 2019 Erika Storck Cezário, Clayton Cássio Thomaz Fróis, et al. This is an open access article distributed under the Creative Commons Attribution License, which permits unrestricted use, distribution, and reproduction in any medium, provided the original work is properly cited. 